\title{
Role of Dietetics in Modern Science
}

\section{MuriumSultan $^{1}$, Muhammad Farooq ${ }^{2 *}$, Hanyue $^{2}$ and Mohamedelfatieh abdelkhalig ${ }^{2}$}

${ }^{1}$ Institute of Home and Food Science Government College, University Faisalabad, Pakistan

${ }^{2}$ College of Food Science and Engineering, Northwest A \& F University Yangling, Shaanxi, China

*Corresponding Author: Muhammad Farooq, College of Food Science and Engineering, Northwest A \& F University Yangling, Shaanxi, China.

Received: June 11, 2019; Published: July 11, 2019

DOI: $10.31080 /$ ASNH.2019.03.0367

\section{Role of Dietitian}

There are many different roles of dietitian such as

- Administrative dietitian

- Clinical dietitian

- Academic dietitian

- Community dietitian

- Consultant dietitian

- Research dietitian

Administrative dietitian

Health professionals responsible for quality and quantity of food for patients and to manage all matters regarding diet department and patient's diet. They work as a supervisor or head of the department.

Clinical dietitian

Working with clinical dietician includes

- Assessment

- Calculations according to needs

- Diet planning

- Counseling

- Evaluation and follow up

Academic dietitian

- Provides and teaches the skills of nutrition and dietetics to the students, doctors and nurses.

- Office management is also a part of the job of a dietitian

- Obesity is not treated by medical therapy. It is treated by cosmetic therapy

\section{Community dietitian}

Community dietitian work with the wellness programs, public health agencies, home care agencies and health maintenance organizations. These dietitians apply and disturb knowledge about food and nutrition to the individuals and groups of specific categories, lifestyles and geographic areas in order to promote health.
They also focus on:

- Needs of elderly, children and other individuals with special needs

- Some conduct home visits to patients who are too physically ill to consult in health facilities

- Provide care and instruction on grocery shopping and food preparation

\section{Consultant dietitian}

Dietitians who are in private practice or practice on contractual basis with healthcare facilities or corporations, such as used in Australia, Canada and the United States.

Consultant's dietitians contract independently to provide:

- Nutrition or health-related consultation

- Educational programs for individuals and healthcare facilities as well as sports teams, finess clubs and other health-related businesses and corporations

\section{Research dietitians}

Research dietitians may focus on social sciences or health services research, for example- investigate the impact of health policies or behavior change, or evaluate program effectiveness. They may survey food service systems management in order to guide quality improvement.

\section{Nutrition assessment}

Anthropometry

Calculations of Calorie Requirements

Total Calorie Requirements $=$ Bee $\times$ Activity Factor $\times$ Injury Factor Basal Energy Expenditure (BEE) Or Harris-Benedict Equation

\section{BEE for Male}

$66.5+(13.7 \times w t$ in $\mathrm{kg})+(5 \times$ height in $\mathrm{cm})-(6.8 \times$ age $)$

\section{BEE for Female}

$655.1+(9.6 \times w t$ in $\mathrm{kg})+(1.85 \times$ height in $\mathrm{cm})-(4.7 \times$ age $)$

$\mathrm{Wt} .=\mathrm{kg}, \mathrm{ht}=\mathrm{cm}$, age $=$ years 


\section{Activity factor}

- $\quad$ No Activity 1.0-1.1

- Slightly Active 1.1-1.3

- Moderate Active 1.3-1.5

- $\quad$ Athlete's Activity 1.5-1.7

Injury factor

Surgery

- Minor 1.0-1.1

- Major 1.3-1.9

Infection

- $\quad$ Mild 1.0-1.2

- Moderate 1.2-1.5

- $\quad$ Severe 1.4-1.8

\section{Calculation of ideal body weight}

- IBW FOR MEN: $106 \mathrm{lb}$. for first 5 feet and $6 \mathrm{lb}$. for each additional inches

- IBW FOR FEMALE: $100 \mathrm{lb}$. for first 5 feet and $5 \mathrm{lb}$. for each additional inches

Calculation of Body Mass Index

BMI= WEIGHT $(\mathrm{kg}) /$ HEIGHT $\left(\mathrm{m}^{2}\right)$

\begin{tabular}{|l|c|c|}
\hline \multicolumn{1}{|c|}{ Standard BMI } & Women & Men \\
\hline Underweight & $<18.5$ & $<18.5$ \\
\hline Desirable weight & $18.5-24$ & $20-25$ \\
\hline Over weight & $25-30$ & $25-30$ \\
\hline Obese grade 1 & $30-35$ & $30-35$ \\
\hline Obese grade 2 & $35-40$ & $35-40$ \\
\hline Obese grade 3 & $40-45$ & $45-50$ \\
\hline
\end{tabular}

Table 1

Wrist Circumference

$\mathrm{r}=$ height $(\mathrm{cm}) /$ Wrist Circumference $(\mathrm{cm})$

\begin{tabular}{|l|c|c|}
\hline Male & Female & Frame \\
\hline $\mathrm{r}>10.4$ & $\mathrm{r}>11.0$ & Small \\
\hline $\mathrm{r} 9.6-10.4$ & $\mathrm{r} 10.1-11$ & Medium \\
\hline $\mathrm{R}<9.6$ & $\mathrm{R}<10.1$ & Large \\
\hline
\end{tabular}

Table 2

Benefits of seeds and nuts

Seeds

Anise seeds

It is used for upset stomach, intestinal gas and as an expectorant to increase productive cough. It is also used as diuretic to increase urine flow and as appetite stimulant.
Basil seeds

It is used for weight loss, used for healthy skin, acidity, diabetes treatment and reduce constipation. It acts as an anti-inflammatory cooling effect in summer time.

\section{Cantaloupe (musk melon seeds)}

Used for healthy growth of hair and nail. Contain fat soluble vitamins $\mathrm{A}$ and $\mathrm{E}$ which enhances antioxidant activity. Good source of $\mathrm{K}, \mathrm{Mg}$ and $\mathrm{P}$.

\section{Caraway seeds}

Used for heartburn, bloating, loss of appetite, and mild spasms of stomach and intestine.

\section{Cardamom}

Used to make medicines, also used for digestive issues, heartburn, intestinal spasm, irritated bowl syndrome, intestinal gas, constipation, liver and gallbladder.

\section{Thymol seeds}

Keep stomach strong, rich in fiber, minerals and antioxidants. Used in acidity indigestion. To treat common cold, cleaning wounds and eases pain due to arthritis.

\section{Coriander seeds}

Lower the blood sugar level and blood pressure. Improve cholesterol, support healthy menstrual function and eases digestive discomfort.

\section{Cumin seeds}

Boost immune system and treat respiratory disorders. Treat insomnia and prevent diabetes. High source of iron.

\section{Fennel seeds}

Used for constipation irritable bowel syndrome and Bloating.

\section{Mustard seeds}

Used for cold painful joints, muscles and arthritis. Used for vomiting and edema by increasing urine production and increase appetite.

\section{Flax seeds}

Reduce risk of heart diseases, cancer, stroke and diabetes. It contains omega-3 lignin and fibers.

Nigella

Having ant carcinogenic property. It keeps a check on diabetes, memory and elevation of asthma, headache, and weight loss, eases joint pain and protect kidney. 


\section{Pepper corn seeds}

Prevent cancer, lower blood pressure, helps in weight loss, cough and cold, increase brain health and treat diabetes. It contains antioxidants.

\section{Pomegranate seeds}

Reduce arthritis and joint pain, fight with cancer, lower blood pressure, improves heart health and rich in fiber.

\section{Pumpkin seeds}

Anti-diabetic and improves lover and heart health.it acts as an anti-inflammatory and immune support.

\section{Fenugreek seeds}

Improves digestive problems and cholesterol level. Reduce inflammation inside the body. Promotes milk flow in breastfeeding.

\section{Dill seeds}

Helps to reduce depression, lower cholesterol. May treat epilepsy, protect against free radicles. Aids in digestion through beneficial fatty acids.

\section{Sesame seeds}

High source of lowering cholesterol. Protect heart health. Improve blood pressure. Fight cancer. Help burn fat. Balance the hormones.

\section{Sunflower seeds}

Reduce risk of heart diseases. Help to prevent cancers. Support thyroid functions. Improves skin health and wards off diabetes.

\section{Nuts}

Almonds

It helps to lower the cholesterol level and prevent cancer. It can prevent heart diseases and heart attacks. It supports healthy functions

\section{Brazil nuts}

They are anti-inflammatory. It improves hormonal functions. Brazil nuts are beneficial to treat acne and weight loss program. Boost immune system.

\section{Cashews nuts}

Improves bone mineral density. It also relieves digestive issues and prevent diabetes. It also improves immune system and lower blood pressure.

\section{Coconut}

It has anti-viral, anti-bacterial, anti-fungal and anti-parasitic property. It improves digestion and absorption of nutrients and it helps to store and support thyroid function.

\section{Hazel nuts}

They promote heart health, lowers LDL cholesterol. It also helps to manage diabetes. Boost the brain health. It also relieves inflammation and in anemia treatment.

\section{Peanuts}

It fight against stomach cancer, heart diseases, nervous diseases, Alzheimer and infection. It also protect skin and have antioxidant property.

Pistachio

It increases absorption of iron and prevents anemia. It improves heart health. It is beneficial for weight management and also improves digestion.

Soy nuts

It lowers the blood pressure and maintain heart health. It is rich in protein. It is frat food to snack on. It also helps to manage weight and maintain heart health.

\section{Walnuts}

They boost bone health. Improves metabolism, regulate sleep and prevent cancer. It also works as mood booster. It is beneficial for skin and control diabetes.

\section{Tiger nuts}

It is healthy substitute for lactose intolerance. It helps against cardiovascular diseases

\section{Diseases and diet plans}

General Considerations for Diet Plan

1. Order of food groups Fruits Bread and cereals Meat and meat products Vegetables Milk and milk products Fat

2. Food must be given 30mins before meal No canned fruits Seasonal fruits only

3. Bread and cereals should be whole not processed

4. 1 serving of egg in breakfast is must. Lean meat is preferred. No preserved or processed meat

5. Raw form of vegetables in one of the major meal is must. No canned and starchy vegetables

6. Natural milk is proffered No milk pack 1 serving of Milk at bed time is must

7. Olive oil, Desi ghee. No saturated fat 
Exchange list

\begin{tabular}{|l|c|c|c|c|}
\hline \multicolumn{1}{|c|}{ Food list } & Carbs & Fat & Protein & Calories \\
\hline $\begin{array}{l}\text { Carbohydrates } \\
\text { Starch, bread, cereals, } \\
\text { grains, starchy veg- } \\
\text { etables, snacks, beans, } \\
\text { peas }\end{array}$ & 15 & $0-1$ & $0-3$ & $80 \mathrm{kcal}$ \\
\hline Fruits & 15 & - & - & $60 \mathrm{kcal}$ \\
\hline Milk & & & & \\
\hline Fat free, low fat &, & $0-3$ & 8 & $100 \mathrm{kcal}$ \\
\hline Reduced fat & 12 & 5 & 8 & $120 \mathrm{kcal}$ \\
\hline Whole & 12 & 8 & 8 & $160 \mathrm{kcal}$ \\
\hline Sweets and deserts & 15 & Varies & Varies & Varies \\
\hline $\begin{array}{l}\text { Meat and meat substi- } \\
\text { tutes }\end{array}$ & & & & \\
\hline Lean & - & $0-3$ & 7 & $45 \mathrm{kcal}$ \\
\hline Medium fat & - & $4-7$ & 7 & $75 \mathrm{kcal}$ \\
\hline High fat & - & 8 & 7 & $100 \mathrm{kcal}$ \\
\hline Plant based proteins & Varies & Varies & 7 & Varies \\
\hline Fats & - & 5 & - & $45 \mathrm{kcal}$ \\
\hline Alcohol & Varies & - & - & $100 \mathrm{kcal}$ \\
\hline Vegetables & 5 & - & 2 & $25 \mathrm{kcal}$ \\
\hline
\end{tabular}

Table 3

BMI and Health

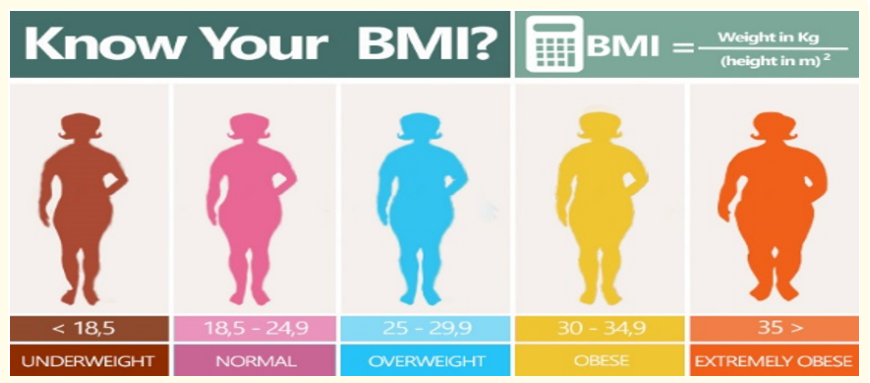

Figure 1

\section{Causes}

Fat cell development Set point theory Genetics and epigenetics Environment Overeating Physical inactivity Sleep and stress Taste, satiety and portion sizes.

\section{Health risk and complications}

Coronary heart disease Dyslipidemia. Liver and gall bladder disease Osteoarthritis Cancer Diabetes. Sleep apnea Social and psychological consequences PCO's and pregnancy problems.
Weight loss strategies and MNT

- Set reasonable goals, be realistic about energy intake, Emphasize nutritional adequacy

- $\quad$ Eat small portions, eat slowly, Lower energy density, Remember water, Focus on fiber

- Choose fats and CHO carefully, Watch for other empty calories

Choose CHO wisely

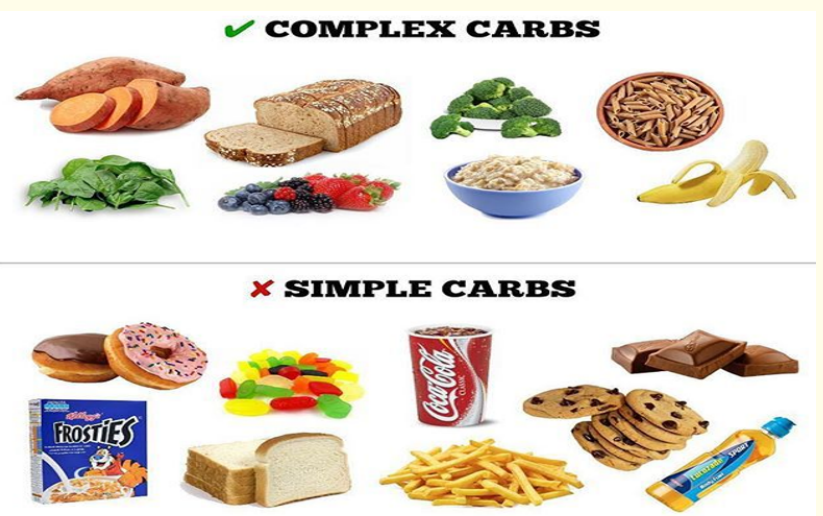

Figure 2

- Include at least 2-3 nuts or seeds in diet. Include fiber in your diet via fruits and vegetables

- They are loaded with fiber, vitamins and minerals. Consume at least 2-3 servings of vegetables and 3-4 servings of fruits. Drink at least 10- 12 glasses of water per day

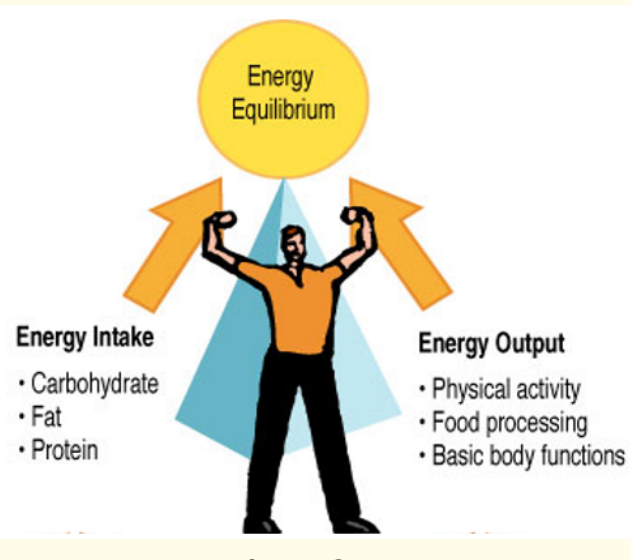

Figure 3

Gestational diabetes

Gestational diabetes only happens during pregnancy. It means you have high blood sugar levels, but those levels were normal before you were pregnant. After your baby is born, gestational diabetes usually goes away. Gestational diabetes makes you more likely to develop type 2 diabetes, but it won't definitely happen. 


\section{AVOID DIABETES}

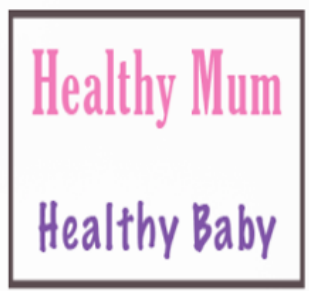

Figure 4

\section{Causes}

During pregnancy, the placenta makes hormones that can lead to a buildup of glucose in your blood. Usually, your pancreas can make enough insulin to handle that. If not, your blood sugar levels will rise and can cause gestational diabetes. It may be due to: Family history Physical stress If mother is alcoholic or smoker High BP.

\section{Diagnosis}

Gestational diabetes usually happens in the second half of pregnancy. Your doctor will check to see if you have gestational diabetes between weeks 24 and 28 of your pregnancy. You doctor may test sooner if you're at high risk. To test for gestational diabetes, you will quickly drink a sugary drink. This will raise your blood sugar levels. An hour later, you'll take a blood test to see how your body handled all that sugar. If the results show that your blood sugar is higher than a certain cutoff (anywhere from 130 milligrams per deciliter $[\mathrm{mg} / \mathrm{dL}]$ or higher), you will need more tests. This means testing your blood sugar while fasting and a longer glucose test that will be done over a 3-hour period. If your results are normal but you have a high risk of getting gestational diabetes, you may need a follow-up test later in your pregnancy to make sure you still don't have it.

\section{Symptoms}

Gestational diabetes doesn't usually cause any symptoms. Most cases are only picked up when your blood sugar level is tested during screening for gestational diabetes. Some women may develop symptoms if their blood sugar level gets too high (hyperglycemia), such as: Increased thirst needing to pee more often than usual. A dry mouth. Tiredness. Itches frequently infections slow healing in cuts

Diet

- Choose foods high in fiber and low in fat and calories. Focus on fruits, vegetables and whole grains. Don't skip the meals, eat a good breakfast. Limit your intake of foods and beverages that contain simple sugars such as soda, fruit juice, flavored teas and flavored waters, and most desserts - or avoid them altogether

- Eat more protein. Protein rich foods such as fish, chicken, and turkey. Eggs, beans, nuts, seeds, legumes.

Foods to avoid

Fast food

- Alcoholic beverages, which you should avoid anyway if you're pregnant

- Baked goods, such as muffins, donuts, or cakes

Fried food

- $\quad$ Sugary drinks, such as soda, juice, and sweetened beverages

Candy

- Very starchy foods, such as white potatoes and white rice

Diet plan for calories 1600-1800

\begin{tabular}{|l|c|c|c|}
\hline \multicolumn{1}{|c|}{ Timings } & Food items & Servings & Kcal \\
\hline Pre breakfast & Almonds & 1 & 45 \\
\hline Breakfast & Cooked oats & 2 & 160 \\
& Medium sized plum & 1 & 60 \\
& 1 boiled egg & 1 & 75 \\
& 1 cup greek yogurt & 1 & 120 \\
\hline Snack 1 & 3/4 cup blue berries & 1 & 60 \\
\hline Lunch & 1 chapatti & 2 & 160 \\
& Chicken gravy & 2 & 150 \\
& Vegetable salad & 1 & 25 \\
& 1 medium apple & 1 & 60 \\
& Seasoned with olive oil & 1 & 45 \\
\hline Snack 2 & Guava & 1 & 60 \\
& 1 cup chicken soup & 2 & 150 \\
& Vegetables added & 1 & 25 \\
\hline Dinner & 1 chapatti whole grain & 2 & 160 \\
& Fish & 2 & 150 \\
& Strawberries & 1 & 60 \\
& Vegetable salad & 1 & 25 \\
\hline Snack 3 & 1 cup skimmed milk & 1 & 120 \\
\hline Total & & & 1710 \\
\hline
\end{tabular}

Table 4

Case study for Hypertension

Name: Abid Nazir

Height: $4.10 "$

Weight: $60 \mathrm{~kg}$

Male

\section{BMI (BODY MASS INDEX)}

Weight $=60 \mathrm{~kg}$

Height $=4.10^{\prime \prime}=2.1 \mathrm{~m}^{2}$ 
BMI = weight $(\mathrm{kg}) /$ height $\left(\mathrm{m}^{2}\right)$

$=60 / 2.1$

$=28.5 \mathrm{~kg} / \mathrm{m}^{2}-$ OVERWEIGHT

Ideal body weight

106 for first 5 inches of male and $6 \mathrm{l}$ bsfor each additional inch.

Height $=4.10^{\prime \prime}$

$=106-2 \times 6$

$=88 / 2.2$

$=40 \mathrm{~kg}$

BMR (Basal Metabolic Rate)

$66.5+(13.7 \times$ wt in $\mathrm{kg})+(5 \times \mathrm{ht}$ in $\mathrm{cm})-(6.8 \times$ age $)$

$66.5+(13.7 \times 60)+5(147)-6.8 \times 52$

$66.5+822+735-354$

$1270 \mathrm{kcal}$

Range - 1200- 1400
Fluid needs

$1500 \mathrm{ml}$ for first $20 \mathrm{~kg}$ and $25 \mathrm{ml}$ for each additional $\mathrm{kg}$

Weight $=60 \mathrm{~kg}$

$=1500+40$ (25)

$=10$ glasses $/$ day

Range 10 - 12 glasses/day

No of servings

STARCH $=7$

VEGETABLES $=4$

FRUITS $=5$

MILK $=2$

MEAT $=2$

FATS $=2$

Carbohydrates $=224 \mathrm{~g}$

Proteins $=59 \mathrm{~g}$

Fats $=24 \mathrm{~g}$

Calories $=1340(1200-1400)$

Distribution of calories

\begin{tabular}{|l|c|c|c|c|c|c|c|c|}
\hline \multicolumn{1}{|c|}{ Food groups } & Total servings & Pre breakfast & Breakfast & Snack 1 & Lunch & Snack 2 & Dinner & Snack 3 \\
\hline Starch & 7 & & 2 & 1 & 2 & - & 2 & - \\
\hline Vegetables & 4 & & - & - & 2 & - & 2 & - \\
\hline Fruits & 5 & & 1 & - & 2 & 1 & 1 & - \\
\hline Milk & 2 & & 1 & - & - & - & - & 1 \\
\hline Meat & 2 & & 1 & - & - & - & 1 & - \\
\hline Fats & 2 & 1 & - & - & - & - & 1 & - \\
\hline
\end{tabular}

Table 5

Diet plan

\begin{tabular}{|c|c|c|c|c|c|}
\hline Timings & Food groups & Carbs & Proteins & Fats & Calories \\
\hline Pre breakfast & $\begin{array}{l}\text { Warm water }+1 \text { fist of hazel } \\
\text { nuts }(1 \text { ser })\end{array}$ & & & $5 g$ & 45 \\
\hline Breakfast & $\begin{array}{c}\text { Bread (2 ser) } \\
\text { Boiled egg } 1 \text { ser } \\
\text { Peach juice } 1 \text { ser } \\
\text { Yogurt fat free } 1 \text { ser }\end{array}$ & $\begin{array}{l}30 \mathrm{~g} \\
15 \mathrm{~g} \\
12 \mathrm{~g}\end{array}$ & $\begin{array}{l}6 \mathrm{~g} \\
7 \mathrm{~g} \\
8 \mathrm{~g}\end{array}$ & $\begin{array}{l}2 \mathrm{~g} \\
4 \mathrm{~g} \\
1 \mathrm{~g}\end{array}$ & $\begin{array}{c}160 \\
75 \\
60 \\
100\end{array}$ \\
\hline Snack 1 & Black grams 1 ser & $15 \mathrm{~g}$ & $3 g$ & $1 \mathrm{~g}$ & 80 \\
\hline Lunch & $\begin{array}{c}\text { Chapatti } 2 \text { ser } \\
\text { Cooked vegetables } 2 \text { ser } \\
\text { Banana } 2 \text { ser }\end{array}$ & $\begin{array}{l}30 g \\
10 g \\
30 g\end{array}$ & $\begin{array}{l}6 \mathrm{~g} \\
4 \mathrm{~g}\end{array}$ & $2 \mathrm{~g}$ & $\begin{array}{c}160 \\
50 \\
120\end{array}$ \\
\hline Snack 2 & Blackberries 1 ser & $15 \mathrm{~g}$ & & & 60 \\
\hline Dinner & $\begin{array}{c}\text { Apple juice } 1 \text { ser } \\
\text { Chapatti } 2 \text { ser } \\
\text { Kabab } 1 \text { ser } \\
\text { Vegetable soup } 2 \text { ser } \\
\text { Olive oil } 1 \text { ser } \\
\end{array}$ & $\begin{array}{r}15 \mathrm{~g} \\
30 \mathrm{~g} \\
10 \mathrm{~g}\end{array}$ & $\begin{array}{l}6 g \\
7 g \\
4 g\end{array}$ & $\begin{array}{l}2 g \\
1 g \\
5 g\end{array}$ & $\begin{array}{c}60 \\
160 \\
45 \\
50 \\
45\end{array}$ \\
\hline Snack 3 & Milk 1 ser & $12 \mathrm{~g}$ & $8 g$ & $1 \mathrm{~g}$ & 100 \\
\hline
\end{tabular}

Table 6 


\section{Conclusion}

This internship I have been a very good experience for me in the way that it has given me the chance to understand the real outside the world and also have learnt lot of my interpersonal skills and self-confidence have improved significantly. Working here is this hospital with the great experience. The environment at the hospital was safe and conducive to learning. Whole staff of the Hospital was cooperative. There was also the moment when we were sad as to see different patients in pain and listening their harmful stories. There were also the moments that were quite satisfying as to see the patients recovering from their illness and it was pleasing to see them leave the hospital healthy again. During my this internship a learnt a lot gain too much practical knowledge, to work in professional manners, establish a professional relationship and interact with patients, improve clinical knowledge, deal with patient effectively and appropriate, how to react with patients family members, how to behave in hospital, to make diet plan and MNT suggestions and find out through nutritional assessment that which patient required early nutritional intervention.

\section{Volume 3 Issue 8 August 2019}

(C) All rights are reserved by Muhammad Farooq., et al. 